\title{
IAMJ
}

INTERNATIONAL

AYURVEDIC

MEDICAL JOURNAL

\section{MUKHA KRIYAKALPA - PROCEDURES FOR PREVENTION AND MANAGEMENT OF ORAL CAVITY DISORDERS}

\author{
Sujata Magi ${ }^{1}$, Veerayya R Hiremath ${ }^{2}$, Shashikala D K ${ }^{3}$, Gururaj N ${ }^{4}$ \\ ${ }^{1}$ PG Scholar, ${ }^{2}$ HOD \& Professor, ${ }^{3}$ Associate Prof, ${ }^{4}$ Assistant Prof \\ Department of Shalakya Tantra, Shree Jagadguru Gavisiddeshwara Ayurvedic Medical College, \\ Koppal, Karnataka, India
}

Corresponding Author: SujataMagi5@gmail.com

https://doi.org/10.46607/iamj1009122021

(Published Online: December 2021)

Open Access

(C) International Ayurvedic Medical Journal, India

Article Received: 30/11//2021 - Peer Reviewed: 10/12/2021 - Accepted for Publication 11/12/2021

\section{Check for updates}

\begin{abstract}
Mukha (oral cavity) is considered as a gateway for the alimentary canal, health of the oral cavity reflects the body health as healthy oral cavity aids in proper digestion of the food consumed. The oral cavity also takes part in bodily functions like respiration and speech. It also contributes to the beauty and confidence of an individual. Mukha is comprised of Osta (lips), Dantamula (Gums), Danta (Tooth), Jinhva (Tongue), Taalu (Palate), Gala (Throat). Since the Oral cavity is constantly exposed to the external environment, there are more chances of trauma and infections. Hence to avoid the chances of oral cavity diseases it is very important to maintain good oral hygiene. Kriyakalpa is the therapeutic procedure applied locally and are considered under bahirparimarjana chikitsa. Kavala, Gandusha and Pratisarana are kriyakalpas explained for good oral hygiene. These can be used as a daily regimen to maintain good oral hygiene and in mukharoga as therapeutic procedures. These mukha kriyakalpadue to their cleaning action and by increasing defence mechanism, promotes oral health and prevents many oral disorders. Various formulations for mukha kriyakalpa are available for a healthy person based on prakriti and for treatment based on vitiated dosha avastha.
\end{abstract}

Keywords: Mukha kriyaklpa, Oral hygiene, kavala, Gandusha, Pratisarana. 


\section{INTRODUCTION}

The oral cavity is constantly exposed to many risk factors in day-to-day life viz, exogenous toxins like external environmental toxins and endogenous toxins like the formation of ama due to consumption of contaminated foods-drinks-air, junk food habits and addictions like tobacco-guthaka chewing, smoking, alcohol intake, irregular food habits etc. results in accumulation of toxins in the oral cavity and cause bacterial invasion leading to bad oral hygiene. The basic activities of the individual like chewing and swallowing food, social communication like smiling, speaking is dependent on oral health. Oral health plays an important role in preventing systemic diseases also. Hence in order to maintain good oral hygiene, it is very important to remove such toxins from the mouth. Mukha is one among 9 bahirmukha srotas (external openings), Part of Urdhwajatru (head \& neck), which gives shelter to rasanendriya (organ of taste perception) and vagindriya (organ of speech production). It is our prime duty to take good care of the oral cavity, failure of which results in oro-dental diseases. Ayurveda recommends the use of mukha kriyakalpa such as kavala, gandusha, pratisarana to remove accumulated toxins safely from the oral cavity.

\section{GANDUSHA AND KAVALA Definition ${ }^{1}$}

Gandusha: One should hold the liquid (Swarasa, Kashaya, Taila, Sukoshna jala, Grita, Kanji) inside the mouth to its full capacity without any movement is known as gandusha.

Kavala: Half of the mouth is filled and should move kalka or liquid in mouth and oropharynx is known as kavala.

\section{TYPES $2,3,4$}

Table 1 - Types of kavala and gandusha according to different acharyas

\begin{tabular}{|l|l|r|}
\hline Sushruta & Vagbhata & Sharangadhara \\
\hline 1. Snehana & 1. Snigdha & 1. Snaihika \\
\hline 2. Prasadana & 2. Shaman & 2. Shamana \\
\hline 3. Shodhana & 3. Shodhana & 3. Shodhana \\
\hline 4. Ropana & 4. Ropana & 4. Ropana \\
\hline
\end{tabular}

- Dravya used for kavala and gandusha ${ }^{5}$

For kavala: Kalka (paste)

For Gandusha: Drava (liquid)

Table 2: Rasa, Guna and doshagnata of kavala and gandusha ${ }^{6,7}$

\begin{tabular}{|l|l|l|l|}
\hline Kavala / Gandusha & Doshagnata & Rasa & Guna \\
\hline 1.Snigdha & Vata & Madhura, Amla, Lavana & Snigdha, Ushna \\
\hline 2.Shamana/Prasadana & Pitta & Tikta, Kashaya, Madhura & Sheeta \\
\hline 3. Shodhana & Kapha & Katu, Amla, Lavana & Ruksha, Ushna \\
\hline 4.Ropana & Vrana & Kashaya, Tikta, Madhura, Katu & Ushna \\
\hline
\end{tabular}

\section{Dharana vidhi (Procedure) ${ }^{8,9}$} PURVAKARMA

- The patient is made to sit comfortably in a place that is devoid of breeze with light.

- The patient is advised not to drink the liquid.

- The patient must have completed Dantadhavana, Jihwanirlekhana, Malavisarjana Karmas.

- The patient is to be given Abhyanga and Mrudusvedana above the shoulder region that is neck, cheeks and forehead.

- The patient should concentrate only on the procedure.

\section{PRADHANA KARMA}

- The medicated liquid (Taila, Kashaya, Gritamanda, sukoshna jala) or kalka of the desired drug (lukewarm) should be measured and given to the patient.

- In kavala, the Patient is advised to move the dravya (kalka) in between cheeks and then to the oropharynx by tilting the head backwards.

- In gandusha, the Patient is advised to hold the drava (Kwatha) in Mukha Kuhara to its full capacity without moving it. 
Duration: Procedure should be done till the accumulation of kapha in the mouth or until the person gets watery discharge from the nose and eyes (Hardly 510 minutes).

- In this way 3 or 5- or 7-days gargles should be conducted or till he gets samyak laxana.

\section{Paschat Karma}

- After samyak laxana, the medicine is spit out.

- The mouth should be cleaned with warm water.

- Dhumapana should be given.

\section{Pramana:}

According to Asthanga Sangraha ${ }^{10}$

\section{Pravar Matra}

- Here the quantity of liquid used for gargles should be $1 / 2$ of the capacity of the buccal cavity.
- It is indicated in strong patients and the disease exhibiting all the signs and symptoms.

\section{Madyama Matra}

- The quantity of liquid used for gargles should be $1 / 3^{\text {rd }}$ of the capacity of the buccal cavity.

- It is indicated for medium personalities and also in the disease of medium symptoms.

\section{Heena Matra}

- The quantity of liquid used for gargles should be $1 / 4^{\text {th }}$ of the capacity of the buccal cavity.

- It is indicated in delicate persons, mild diseases and persons with pitta prakriti.

According to Shaarangadhara Samhita ${ }^{11}$

- Gandusha dravya: 1 Kola (6gms)

- Kavala dravya: 1 Tola (12gms)

Table 3 - Samyak, Heena, Ati Yoga ${ }^{12}$

\begin{tabular}{|c|c|c|}
\hline SAMYAK YOGA & HEENA YOGA & ATI YOGA \\
\hline $\begin{array}{l}\text { - Vyadherapachaya (Alleviation of dis- } \\
\text { - } \quad \text { Tusti (freshness of mouth) } \\
\text { - Vaktra vaishadya (Clearness of mouth) } \\
\text { - Vaktra laghava (Lightness of mouth) } \\
\text { - Indriyaprasadana (Nourishment of sen- } \\
\quad \text { sory organs) }\end{array}$ & $\begin{array}{l}\text { - Kaphotklesha (Increases kapha } \\
\text { in mouth) } \\
\text { - Rasajnyana (Loss of taste sen- } \\
\text { - } \text { sation) } \\
\text { - Aruchi (Anorexia) }\end{array}$ & $\begin{array}{ll}\text { - } & \text { Paaka (Ulceration in mouth) } \\
\text { - } & \text { Shosha (Dryness) } \\
\text { - } & \text { Trushna (Thirst) } \\
\text { - } \quad \text { Klama (Giddiness) }\end{array}$ \\
\hline
\end{tabular}

Table 4: Dravya Used In Kavala And Gandusha

\begin{tabular}{|c|l|}
\hline Kavala/Gandusha & Dravya \\
\hline 1. Snehana & Mamsarasa, Tilakalka, Milk, jala \\
\hline 2. Shaman/Prasadana & $\begin{array}{l}\text { Patol, asrista, jambu, amra, maltipatra, utpala, madhukakwath, shitodak, iksurasa, milk, } \\
\text { honey and ghrita etc. }\end{array}$ \\
\hline 3. Shodhana & $\begin{array}{l}\text { Sukta, Madhya, kanji, mutra and other kalkas etc. } \\
\text { 4. Ropana } \\
\text { kwath }\end{array}$ \\
\hline
\end{tabular}

Table 5: Indication ${ }^{13}$ And Contraindication ${ }^{14,15}$

\section{Indication}

- Manyasthamba (neck stiffness), Shiroroga (diseases of head), Karna roga (diseases of the ear), Mukha roga (diseases of mouth), Akshi roga (diseases of the eye), Praseka (excessive salivation), Kantha roga (diseases of the throat), Vaktra shosha (dryness of the mouth), Hrillasa (Nausea), Tandra(laziness), Aruchi (Anorexia), Peenasa (Running nose)

\section{Contraindication}

- Below 5years of age

- In Visha (poison), Moorcha (Fainting), Mada (Intoxication), Shosha (Emaciation), Raktapitta (bleeding disorder), Ksheena (weakness) and Rooksha Rogi (Patient with a dry body). 


\section{Mode of Action of Gandusha ${ }^{16}$}

Gandūsha is a form of drug administration into the oral cavity in which the active ingredients and chemical constituents of the drugs are absorbed through the buccal mucosa and reach the bloodstream. It is having both local and systemic action but generally more in local effect. The probable mode of action is explained in the following actions:

Exerts increased mechanical pressure: Gandūsha increases mechanical pressure inside the oral cavity. The active ingredients and chemical constituents of the medicated liquid stimulate the chemoreceptors and mechanoreceptors in the mouth to send signals to salivary nuclei in the brain stem. As a result, the parasympathetic nervous system activity increases, and impulses are sent via motor fibres in facial and glossopharyngeal nerves. They trigger a dramatically increased output of salivary secretion which is predominantly watery (serous). The metabolic waste (toxins), food debris and depositions as well as superficial infective micro-organisms present in the oral cavity gets dislodged and mixed with retained medicated liquid and removed from the oral cavity. Thus, Gandūsha will act as a good oral cleansing method and help to improve or regain oral hygiene.

Stimulates salivary gland: Gandūsha stimulates the salivary glands to secrete more saliva. Saliva contains a variety of host defence factors. The IgA, IgM antibodies and lysozyme (a bactericidal enzyme that inhibits bacterial growth in the mouth) present in the saliva protect micro-organisms by acting as a local antibiotic. Saliva also contains coagulation factors (factors VIII, IX \& X) which protect wounds from bacterial invasion. Hence, Gandūsha increases the local defence mechanism of the oral cavity and helps to regain oral hygiene.

Increases the vascular permeability: Gandūsha increases the vascular permeability in the oral cavity. It creates pressure over the oral mucosa. The active ingredients and chemical constituents of the warm medicated liquid irritate the oral mucosa and increase vascular permeability. Therefore, the drugs get rapidly absorbed both locally and systemically. This can help to reduce inflammation and enhance the healing process of disease and thus cures the disease of the oral cavity.

Maintains oral pH: The main function of the salivary buffer is to maintain $\mathrm{pH}$ at the mucosal epithelial cell surface and the tooth surface. A healthy mouth is non-acidic or neutral. An unhealthy mouth is acidic and increases the risk of oral diseases. Gandūsha is an immediate solution for mouth acidity and changes the oral $\mathrm{pH}$ quickly into a safe zone. The active ingredients and chemical constituents of the medicated liquid of Gandūsha regulate and balance the $\mathrm{pH}$ of the oral cavity and help to reduce bacterial growth in the mouth. Thus, Gandüsha cures the disease and helps to regain oral hygiene by maintaining a good $\mathrm{pH}$ balance in the mouth.

\section{Mode of Action of Kavala ${ }^{17}$}

It has both local and systemic action

\section{Local action}

The drug when moved within the oral cavity creates a pressure that stimulates Presso receptor (stretch reflex) that are present in the mouth. Once the presso receptor is stimulated, the signals are sent to salivary nuclei in the brain stem (pons and medulla). As a result, Parasympathetic nervous system activity increases and motor fibres in the facial (VII) and glossopharyngeal (IX) nerve trigger dramatically increased output of saliva. Chemical constituents present in the drug also stimulate chemoreceptors present in the mouth, which in turn increases salivary secretions. Lysozyme is an enzyme present in the saliva that is bacteriostatic in action which prevents the growth of pathogenic microorganisms in the oral cavity. Antibody IgA present in saliva also protects against microorganisms. Proper absorption of the active principles takes place in the oral cavity due to the pressure created by the action of Kavala.

The enzyme salivary amylase present in saliva and lingual lipase secreted by the lingual gland present at the dorsum of the tongue initiates the digestion of carbohydrates and fats respectively. Kavala increases the secretions of these enzymes. Excessive salivary secretion, which predominantly contains water, removes metabolic wastes present in the oral cavity. Some dravyas used for Kavala like pancha valkala 
produces a soothing effect on lesions like ulcers thus preventing ulcers from physical and chemical injury.

\section{Systemic action}

A thin and highly vascular mucosal layer inferior to the tongue (sublingual) permits the rapid absorption of lipid-soluble drugs into the systemic circulation. The temperature and potency of drugs cause dilatation of blood vessels in the oral mucosa which helps to assimilate the active ingredients from the medicine. Some of the drugs irritate the oral mucosa (by their chemical nature) and increase vascular permeability. Thus, an active principle of Dravya is absorbed into the systemic circulation.

\section{Kavala And Gandusha In Different Conditions}

- Tila kalka and Ushnodaka - Danta harsha, Danta chaala, Mukha roga

- Tila taila or Mansa rasa - Dinacharyaartha

- Madhu Gandusha - Mukha vrana, vaisadya and daha-trisna prasamana

- Tila Tail saindhav - Gandusha in dantachaala

- Kanjika Gandusha - Mukhasosha, mukhaverasya and mala daurgandhyanashak

- Triphalamadhu Gandusha - Kaphaj and raktapittaja mukharoga

- Darvyadi Gandusha - Tridoshaja mukhapaka

- Tila kalkodaka Gandusha - Dantharsha, dantachala and vataja mukharoga

- Trikatukadi kavala - Kaphaja mukharoga

- Sukhosnodaka Gandusha - Mukhalaghuta

- Grita and Ksheera - Daaha, Paaka, Kshata, Agantu roga, Visha, Kshara, Agnidagdha.

- Pippalyadi teeksha dravya kavala dharana kaphaja karna shoola

- Kavala dharana - krimikarna
- Shreevestakaadi kashaya kavala dharana - pittaja Pratishyaya

- Mustadi kavala dharana - sannipataja pratishyayas

- Teekshna gandusha and kapha hara kavala kaphaja shiroroga

- Kavala with shukta, tikta-katu dravya kashaya and madhu - krimija shiroroga

- Kavala - pakvapratishyaya

- Kavala with madhura dravya - pitta-rakta Pratishyaya

- Kavala dharana with mustadi kashaya - all types of Pratishyaya

\section{Pratisarana $^{18}$}

Application of different forms of the drugs inside the mouth with the help of the index finger is known as partisarana

- Pratisarana is used as a paschat karma after Rakthmokshana karma.

- The same drugs which will be useful for gandusha can be used in pratisarana.

Table 6: Types

\begin{tabular}{|l|ll} 
Astanga Hrudaya $^{19}$ & & Sushruta \\
1. Kalka & 1. & Kalka \\
2. Rasakriya & 2. & Rasakriya \\
3. Churna & 3. & Kshaudra \\
& 4. & Churna
\end{tabular}

Matra of Dravya ${ }^{21}$

- $\quad$ kolasti matra (size of jujube seed)

Duration ${ }^{22}$

- Heena dosha-3days

- Madyama dosha-5days

- Uttama dosha-7day

Table 7: Samyak Yoga, Ayoga, Atiyaoga of Pratisarana ${ }^{23}$

\begin{tabular}{|l|l|l|}
\hline Samyak Yoga & Ayoga & Atiyoga \\
\hline Vaishadya (clarity) & Paichilya (stickiness) & Daaha (burning sensation) \\
Laaghava (lightness) & Gurutva (heaviness) & Kleda (salivation) \\
Kshavathu (feeling hungry) & Anannabhilaasha (loss of appetite) & Shvayathu (Gum swelling) \\
Apraseka (No nausea) & Pramoha (Fainting) & Trushna (feeling thirst) \\
Annabhilaasha (craving for food) & Vikara anupashaya (not alleviate & Abhakta (not feeling hungry) \\
& the disease) & Vaaksanga (slurred speech) \\
\hline
\end{tabular}




\section{Method of Pratisarana ${ }^{24}$}

\section{Instructions to the Patient}

All the patients should be advised to follow the instructions during therapy and in the follow-up period:

- Oral hygienic methods should be explained

- Proper brushing by using soft brush 2 times a day morning and evening after meals by using "Bass" method was advised

- Instructions regarding Ahara and Vihara should be given, i.e., fibrous, non-sticky, less sweeten, etc., and proper mastication by using both sides

- Proper rinse of mouth after each meal/food.

\section{Procedure}

Purvakarma

- Patients were advised to do Pratisarana 2 times, morning and evening after proper cleaning of the mouth.

- Choorna should be taken in 1 kola(6gm) quantity and mixed with a very little amount of lukewarm water or honey and make the Choorna in paste form.

\section{Pradhana Karma}

- It should be taken on tip of the index finger and applied all over the gingiva smoothly with gentle pressure for 3-5 min in clockwise, round direction. Finally with slight pressure massage toward the gingival margin should be done and the drug should remain on gingiva for 5 minutes.

\section{Paschat Karma}

- After pratisarana proper rinsing was advised with lukewarm water.

- The same procedure was instructed for the paste and also application has been adopted by using the tip of the finger.

\section{Probable Mode of Action of Pratisarana ${ }^{25}$}

It is the procedure wherein gentle massage is done on gingiva as well as teeth helps in mechanical removal of food debris, Plaque, Necrotic tissue remnants, Inflamed granulation tissue and bacterial colonies. By constant rubbing it produces a pseudo-inflammatory reaction in the tissue, thereby altering the permeability of the blood capillaries and improving drug absorption producing the desired effect. Also, the rate of gingival crevicular fluid production is increased by gingival massage. This crevicular fluid inhibits bacterial diffusion into the tissue as it has phagocytic leukocytes, specific antibodies and enzymes of several specificities. Pratisarana promotes salivation which helps in plaque control and restores normal contour to the gingiva.

\section{Pratisarana In Different Condition}

- Sheetada - Mustadi churna pratisarana.

- Dantapupputa - Panchalavana or Yavakshara mixed with madhu pratisarana.

- Shousheera - Lodradi churna pratisarana.

- Upakusha - Madhu, Saindava lavana, Trikatu churna pratisarana.

- Adhimamsa - Vachadi churna pratisarana.

- Vataja ostakopa - Yashti, Guggulu, Devadaru, Madhuchista

- Pittaja ostakopa - Lodhra, Sariva, Madhuka, Madhu

- Jalarbuda - Trikatu, Madhu, Saindhava, Yavakshara

- Sheetada - Triphala, Shunti, Musta, Sarshapa, Rasanjana churna, Peetaka churna.

- Dantasharkara - Lakshachurna, Madhu

- Chalsadanta - Lodhradi churna, Madhu

- Jihwa kantaka - Guggulu churnal Lodhra churna/ Pippalyadi churna

- Tundikeri - Pippalyadi churna, Peetaka churna

- Mukhapaka - Triphala churna, Madhu/ Darvi rasakriya/ Lavana, Krishna, Ela churna

\section{DISCUSSION}

The aim of mukha kriyakalpa procedures seems to be tissue oriented where the therapeutic concentration of the drug can be achieved by tissue contact time, the molecular weight of the drug, absorption of drug and bioavailability of the drug. The drugs are selected as per vitiated dosha and type of disease for the procedure. The procedures of medication are modulated to attain maximum absorption of the drug. As kavala and gandusha act locally by exerting increased mechanical pressure inside the oral cavity, increasing the oral $\mathrm{pH}$ and stimulating the salivary glands and it also acts systemically by increasing the vascular permea- 
bility, Pratisarana acts by increasing defence mechanism in the oral cavity.

Depending upon the vyaktasthana, rogibala and rogabala, one has to select these sthanika chikitsopakramas. Even in shastrasadhyavyadhi- we can go for kavala, gandusha and pratisarana. These sthanikaupakramas are oral transmucosal administrations, more beneficial because drug absorption is rapid due to rich vascular supply and lack of stratum corneum epidermidis. This results in the rapid rise of drug concentration in blood. Oral transmucosal administration has the advantage of avoiding enterohepatic circulation and immediate destruction by gastric juice.

\section{CONCLUSION}

Ayurveda explained kavala, Gandusha and Pratisarana are some of the daily routine procedures under the context of dinacharya for maintenance of oral hygiene. These are important therapeutic procedures as well as effective detoxifying measures in oral diseases. They will maintain and promote oral hygiene by exerting the cleansing action and by increasing the defence mechanism in the oral cavity. These are having both preventive and curative effect if it is performed systematically. Being students of Ayurvedawe should know the importance of these procedures and make use of them in day-to-day life and in clinical practice and also has additive effect on general health, Daily practising of those may add a further step in the lifestyle of a healthy human being.

\section{REFERENCES}

1. Vrudda Vagbhata: Astanga sangraha, Sutrasthana edited by Dr Shivaprasad Sharma, Chaukamba Sanskrit series office Varanasi, Cha.No/Sl. No-31/5, Pg. No-231.

2. Sushruta: Sushruta samhita, Chikitsa Sthana edited by Dr Keval Krishna Thakaral chawkhamba orientalia, Varanasi Vol-2 Cha.No/Sl. No-40/58, Pg. No- 623.

3. Vagabhata: Astanga hrudaya, Sutrasthana edited by Dr. R Vidyanath, Chaukamba surabharati prakashana Varanasi, Reprint-2016, Cha.No/Sl. No- 22/1, Pg. No328.
4. Sharangadhara: Sharangadhara samhita, Uttara khanda edited by Dr G Prabhakar Rao, chaukhamba publications, New Delhi, Reprint-2016, Cha.no/S1. No- 10/1 and Pg NO-303.

5. Sharangadhara: Sharangadhara samhita, Uttara khanda edited by Dr G Prabhakar Rao, chaukhamba publications, New Delhi, Reprint-2016, Cha.no/S1. No- $10 / 4$ and Pg NO-303.

6. Vagabhata: Astanga hrudaya, Sutrasthana edited by Dr. R Vidyanath, Chaukamba surabharati prakashana Varanasi, Reprint-2016, Cha.No/Sl. No- 22/2-3, Pg. No-328-329.

7. Sushruta: Sushruta samhita, Chikitsa Sthana edited by Dr Keval Krishna Thakaral chawkhamba orientalia, Varanasi Vol-2 Cha.No/Sl. No-40/59-60, Pg. No- 623.

8. Vrudda Vagbhata: Astanga sangraha, Sutrasthana edited by Dr Shivaprasad Sharma, Chaukamba Sanskrit series office Varanasi, Cha.No/Sl. No-31/5, Pg. No-231.

9. Vagabhata: Astanga hrudaya, Sutrasthana edited by Dr. R Vidyanath, Chaukamba surabharati prakashana Varanasi, Reprint-2016, Cha.No/Sl. No- 22/10-11, Pg. No-330.

10. Vrudda Vagbhata: Astanga sangraha, Sutrasthana edited by Dr Shivaprasad Sharma, Chaukamba Sanskrit series office Varanasi, Cha.No/Sl. No-31/5, Pg. No-231.

11. Sharangadhara: Sharangadhara samhita, Uttara khanda edited by Dr G Prabhakar Rao, chaukhamba publications, New Delhi, Reprint-2016, Cha.no/S1. No- 10/5 and Pg No-303.

12. Sharangadhara: Sharangadhara samhita, Uttara khanda edited by Dr G Prabhakar Rao, chaukhamba publications, New Delhi, Reprint-2016, Cha.no/S1. No- 10/19-20 and Pg No-305.

13. Sharangadhara: Sharangadhara Samhita, Uttara khanda edited by Dr G Prabhakar Rao, chaukhamba publications, New Delhi, Reprint-2016, Cha.no/S1. No-10/8-15 and Pg No-304.7

14. Sharangadhara: Sharangadhara samhita, Uttara khanda edited by Dr G Prabhakar Rao, chaukhamba publications, New Delhi, Reprint-2016, Cha.no/Sl. No- $10 / 6$ and Pg NO-303.

15. Acharya Bhavamisra, Bhavaprakasha Translated by Bhishagmishra Shree brahmashankar Mishra, Vol-1, 5/44, Edition 2013, Chaukambha sanskrita bhavana, Pg No-112. 
16. Dr R B Hosamani: A review on Gandusha: An Ayurvedic therapeutic procedure for oral disorders, International Ayurvedic medical journal 2017.

17. Bhat Smitha U.S. \&Waheeda Banu: Role of Kavala in Mukha Swasthya (Oral Hygiene) As Dincharya. International Ayurvedic Medical Journal\{online\} 2018 \{cited May 2018\} Available from: http://www.iamj.in/posts/images/upload/1070_1074.p df

18. Vagabhata: Astanga hrudaya, Sutrasthana edited by Dr. R Vidyanath, Chaukamba surabharati prakashana Varanasi, Reprint-2016, Cha.No/Sl. No- 22/13, Pg. No-332.

19. Vagabhata: Astanga hrudaya, Sutrasthana edited by Dr. R Vidyanath, Chaukamba surabharati prakashana Varanasi, Reprint-2016, Cha.No/Sl. No- 22/13, Pg. No-332.

20. Sushruta: Sushruta samhita, Chikitsa Sthana edited by Dr Keval Krishna Thakaral chawkhamba orientalia, Varanasi Vol-2 Cha.No/Sl. No-40/69, Pg. No- 625.

21. Sushruta: Sushruta samhita, Chikitsa Sthana edited by Dr Keval Krishna Thakaral chawkhamba orientalia, Varanasi Vol-2 Cha.No/S1. No-40/69, Pg. No- 625.

22. Sushruta: Sushruta samhita, Chikitsa Sthana edited by Dr Keval Krishna Thakaral chawkhamba orientalia, Varanasi Vol-2 Cha.No/Sl. No-40/69, Pg. No- 625.

23. Sushruta: Sushruta samhita, Chikitsa Sthana edited by Dr Keval Krishna Thakaral chawkhamba orientalia, Varanasi Vol-2 Cha.No/Sl. No-40/69, Pg. No- 625.

24. Peiris, K P P et al. "A comparative study of Dashana Samskara Choorna Pratisarana and Dashana Samska$r a$ paste application in the management of Sheetada (Gingivitis)." Ayu vol. 34,1 (2013): 63-9. doi:10.4103/0974-8520.115452.

25. M D, K D. practical utility of sthanika chikitsa upakrama in common mukharoga. world journal of pharmaceutical and life sciences WJPLS.2018;4(9):202-205.

\section{Source of Support: Nil \\ Conflict of Interest: None Declared}

How to cite this URL: Sujata Magi et al: Mukha Kriyakalpa Procedures For Prevention And Management Of Oral Cavity Disorders. International Ayurvedic Medical Journal \{online\} 2021 \{cited December 2021\} Available from: http://www.iamj.in/posts/images/upload/2985 2992.pdf 